\title{
A Holistic Approach to Sustainable Development of Energy, Water and Environment Systems
}

Article in Journal of Cleaner Production · January 2017

DOI: 10.1016/j.jclepro.2017.01.119

CITATIONS

0

4 authors, including:

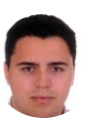

Hrvoje Mikulcic

University of Zagreb

37 PUBLICATIONS 186 CITATIONS

SEE PROFILE

\section{Neven Duic}

University of Zagreb

444 PUBLICATIONS 2,166 CITATIONS

SEE PROFILE

\section{Marc A. Rosen}

University of Ontario Institute of Technology 597 PUBLICATIONS 12,362 CITATIONS

SEE PROFILE

Some of the authors of this publication are also working on these related projects:

Project
SDEWES 2015 Special Issue section of Clean Technology and Environmental Policy journal View project

CoolHeating View project 
Review

\title{
A holistic approach to sustainable development of energy, water and environment systems
}

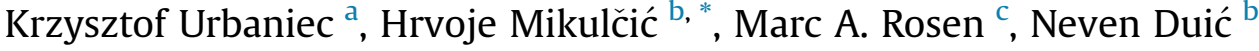 \\ ${ }^{a}$ Warsaw University of Technology, Plock Branch, Jachowicza 2/4, 09-402 Plock, Poland \\ ${ }^{\mathrm{b}}$ Faculty of Mechanical Engineering and Naval Architecture, University of Zagreb, Ivana Lučića 5, 10000 Zagreb, Croatia \\ ${ }^{c}$ Faculty of Engineering and Applied Science, University of Ontario Institute of Technology, Oshawa, Ontario L1H 7K4, Canada
}

\section{A R T I C L E I N F O}

\section{Article history:}

Received 20 January 2017

Accepted 21 January 2017

Available online $\mathrm{xxx}$

\section{Keywords:}

Energy issue

Water

Wastewater

Life cycle assessment

Waste management

Environmental engineering

\begin{abstract}
A B S T R A C T
Due to climate change concerns, various environmental stresses and social inequality among the people, the welfare of mankind is increasingly being viewed through the prism of sustainable development. Sustainable development is a highly multi-disciplinary field of research that has been extensively studied during last two decades. Therefore, from the beginning of the 21st century, a series of Sustainable Development of Energy, Water and Environment Systems (SDEWES) Conferences were founded to address sustainable development issues. This Journal of Cleaner Production Special Volume (SV) is dedicated to the 10th SDEWES Conference. The SV is focused on three main fields that are of strategic importance to sustainable development: energy issues, water issues, and environmental engineering and management. The division of selected papers according to the named research fields was established following the previous Journal of Cleaner Production Special Sections and Volumes dedicated to the SDEWES Conferences. Therefore, this Special Volume builds upon the previously generated SDEWES knowledge base.
\end{abstract}

() 2017 Elsevier Ltd. All rights reserved.

\section{Contents}

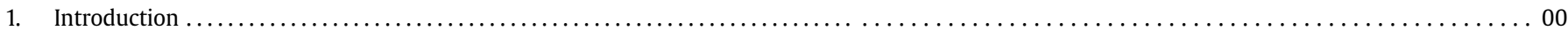

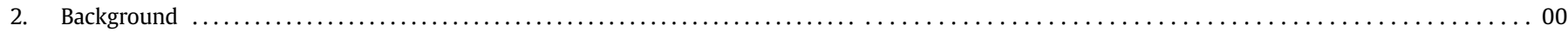

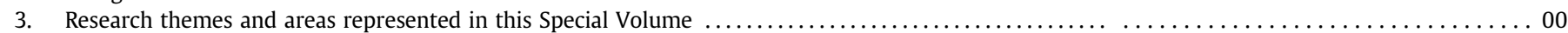

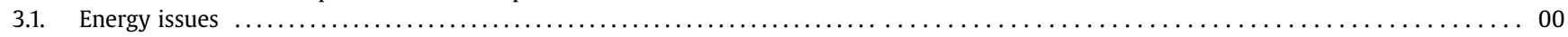

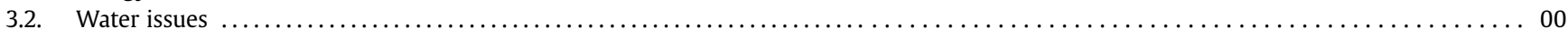

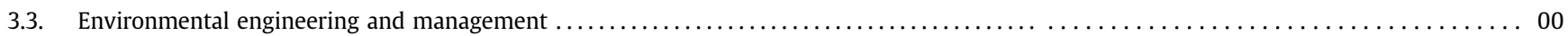

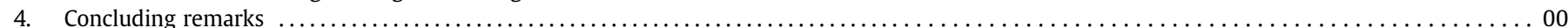

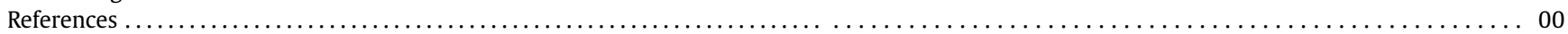

\section{Introduction}

The ideas of sustainability and the closely related concept of sustainable development were most clearly articulated by the World Commission on Environment and Development (WCED,

\footnotetext{
* Corresponding author.

E-mail addresses: k.urbaniec4@upcpoczta.pl (K. Urbaniec), hrvoje.mikulcic@fsb. hr (H. Mikulčić), marc.rosen@uoit.ca (M.A. Rosen), neven.duic@fsb.hr (N. Duić).
}

1987), also known as the Brundtland Commission. It defined sustainable development in "Our Common Future" as that which meets the needs of the present without compromising the ability of future generations to meet their own needs. Sustainability also involves the highly interdisciplinary and multi-cultural evaluation of complex systems.

To address these issues, from the beginning of the 21st century the SDEWES Conference series was established. Over the years, SDEWES Conferences became a significant venue for researchers to meet, and develop, discuss, share, and disseminate new ideas. In 
2015, in the beautiful medieval city of Dubrovnik, Croatia, the 10th SDEWES Conference served as a venue for academic and industry experts, of various disciplines, from all over the world, to meet and to share technical information, providing the opportunity for multidisciplinary discourses on science, technology and environmental policy that have the potential to lead to the development, demonstration, and commercialization of cleaner products and processes and effective environmental policy strategies.

The 10th SDEWES Conference brought together an impressive number of participants (538) from 65 countries, to strengthen the scientific capacities around the world and to ensure that the sciences are responsive to emerging international challenges, especially in terms of the sustainability of humanity's activities. The papers included in this Special Volume (SV) are based on contributions presented at the 10th SDEWES Conference. In total 1204 abstracts were submitted, which resulted in 551 accepted manuscripts. Of those, 30 papers were selected for this Journal of Cleaner Production (JCLP) SV.

As a continuation of cooperation between the Journal of Cleaner Production and the SDEWES Conference series, this SV follows the format of two previous reports on SDEWES 2009 and 2011 (Urbaniec, 2010; Duic and Urbaniec, 2012), and two reviews of the SDEWES 2013 and 2014 (Duić et al., 2015; Urbaniec et al., 2016). Consequently the papers for the present SV SDEWES 2015 can be roughly divided into three research fields that have been established by the previous JCLP SV's dedicated to the SDEWES 2013 and 2014 Conferences: energy issues (13 papers); water issues (5 papers); and environmental engineering and management (12 papers). Hence, the previously generated SDEWES knowledge base is extended by this SV.

\section{Background}

This section provides the background to the main part of this article, that is, papers reviewed under Section 3. It is structured in a way that the backgrounds for the three research fields (energy issues, water issues, and environmental engineering and management) under which the selected papers are classified, are described in more detail. The content of this section is based on the papers published under this and other journal's Special Sections or Volumes dedicated to SDEWES conference series.

Over the past years, papers dealing with energy issues illustrated the complexity of the interlinking of fossil and renewable energy resources, carbon dioxide reduction and rational energy use in various regions of Europe (Dominković et al., 2016; Zakeri et al., 2016), on a national level (Fischer et al., 2016; Heaslip et al., 2016; Komušanac et al., 2016), or in different industrial sectors like cement production (Mikulčić et al., 2015) and coke production (Cheng et al., 2016). Furthermore, increasing attention was given to energy consumption and the potential for energy savings in public buildings. Due to their size and functional requirements, public buildings tend to consume significant amounts of energy, and there is great potential for improving their energy performance (Mohammed and Budaiwi, 2013; Herrando et al., 2016; Horvat and Dović, 2016).

There is growing evidence that climate change is accelerated by human activities including fossil fuel consumption. Therefore, researchers are increasingly investigating ways to improve and rationalize the use of fossil fuels. As the production of power is still heavily dependent on fossil fuels, making this sector one of the biggest greenhouse gas emitters, the transition of power production from non-renewable to renewable resources was recognized as important in numerous publications exemplified by Walmsley et al. (2014). In one study, Kazagić et al. (2014) provided guidelines and principles for power utilities to reach specific energy and decarbonisation targets. The proposed method of optimization of the power generation portfolio, as a function of sustainability and decarbonisation, was applied to a real-life power system, the power utility JP Elektroprivreda BiH d.d., Sarajevo (Bosnia and Herzegovina), and the results showed a potential for a $49 \% \mathrm{CO}_{2}$ emissions reduction in 2030 compared to 1990 levels, along with a further increase in overall energy efficiency of the system and high penetration of renewable energy resources.

Numerous studies have evaluated the economic, energy, environmental and sociological aspects of substituting fossil fuels with renewable ones (Koziol and Mendecka, 2015; Nogueira de Oliveira et al., 2016). As shown in the latter work, although the substitution of fossil fuels presents a significant environmental potential, fossil fuels will still play an important role. The study indicated that, given uncertainties regarding the long-term future, decisions to invest in innovation are risky and therefore should account for the stage of technology and knowledge development in different countries. In Brazil, the most relevant innovation potential was found in the biomass and wind sectors, and in ethanol production combined with carbon capture.

Partial substitution of fossil fuels with alternative solid fuels, such as biomass and waste-derived fuels, has already been recognized as an advantageous method for greenhouse gas mitigation. However, due to the different properties of those fuels and their varying performances in existing combustion systems, their applications are still being studied both experimentally and numerically (Mikulčić et al., 2016a, 2016b).

As biomass is a renewable fuel that can easily substitute fossil fuels (Mikulčić et al., 2014), the production, analysis and utilization of various types of biomass have attracted much research. Biomass productivity in arid and semi-arid areas was investigated by Houri and Machaka-Houri (2016). Focusing on the utilization of biomass for generating various forms of valuable products, the increasing availability of agriculture residues was studied by Bing et al. (2016) and Mikulandrić et al. (2016a). Biomass gasification in a co-current fixed bed gasifier was considered by Mikulandrić et al. (2016b), and previously by Sriwannawit et al. (2016). Bioethanol production from microalgal biomass was investigated by Muei Chng et al (2016) and Silva et al. (2016). These two studies demonstrated that technologies for biomass conversion to bioethanol are energy intensive and that the produced biofuel can be either used directly in a generator set to produce electricity or upgraded to produce transportation fuels. Dias et al. (2016) discussed the competition of land use between biodiesel production and food production, and concluded that the production of biodiesel, under specific regulatory and production conditions, could become a driver of economic development.

Next to the electricity and heat generation sector, the transportation sector is one of the largest energy consumers worldwide. Therefore fuel consumption, efficiency improvement and fuel substitution for conventional internal combustion (IC) engines were intensively studied (Degiuli et al., 2017; Petranović et al., 2017). Typical research on diesel engines is represented by the studies of Petranović et al. (2015) and Vujanović et al. (2016), and on spark ignition engines by the study of Wang et al. (2015). As the transportation sector is a major pollutant emitter, pollution reduction measures have also attracted significant attention (Baleta et al., 2015, 2016). It was reported that the transition from conventional IC engines to electric drives has the greatest potential for overall energy demand reduction in the transportation sector ( $\mathrm{Knez}$ and Obrecht, 2016; Škugor and Deur, 2016). Teixeira and Sodré (2016) evaluated the potential effects of the replacement of conventional IC engine vehicles by electric vehicles on carbon dioxide emissions and energy consumption. According to their results, obtained according to a standard test procedure, electric energy 
consumption by electric vehicles is about four times lower than fuel energy consumption by conventional vehicles, and carbon dioxide emissions are lower by a factor of 10 .

Among papers dealing with water issues, the availability and supply security of fresh water for household consumption was investigated on several levels of complexity and for different climates. Romano et al. (2016) discussed factors affecting household water consumption in major Italian towns. Fresh water production employing membrane distillation driven by salt-gradient solar ponds was studied by Suárez and Urtubia (2016). García-Montoya et al. (2016) considered the design of residential water networks in a water-stressed region in central Mexico. Groundwater extraction from the public water supply source was investigated by Polomčić et al. (2015) who analyzed the impact of industrial activity on the regime of water supply, and the radius of influence of these activities on the groundwater source over a period of 200 days. Water demand management programs, such as retrofitting households with water-efficient devices and appliances, in remote communities on islands and in isolated mainland townships, was investigated by Beal et al. (2016). Better matching between water supply and demand was studied from a holistic perspective by Anzaldi (2014) who showed that near real-time knowledge on water supply and demand, from sources to users, across geographic and organizational scales, ensures maximum usability of water. Water management and reuse as parts of industrial activities were considered as well. Colla et al. (2016) studied water reuse and facility management concepts for steel plants, Boldyryev et al. (2016) investigated water flows for heat transfer inside a cement plant, Ozturk et al. (2016) performed water, wastewater, and chemical minimization studies in a textile mill. Papers dealing with wastewater treatment indicated the need for further research on various topics including reduction of toxic heavy metal ions (Ananpattarachai and Kajitvichyanukul, 2016; Laskar et al., 2016), elimination of bioactive nanoparticles (Puay et al., 2015; Qiu et al., 2016), and mitigation of acid mine drainage (Clyde et al. (2016). Upgrading of wastewater treatment plants was analyzed by Hvala et al. (2017) and life cycle assessments of such plants in Ireland were performed by McNamara et al. (2016). The latter study showed that energy consumption and sludge application to land are the largest contributors to the overall environmental impact associated with wastewater treatment.

Over the years, papers in the field of environmental engineering and management, included studies on the environmental impact of various industrial activities, the formation and reduction of air pollutants, ecological harm and devastation, as well as waste minimization, recycling and management. The method of life cycle assessment has become extensively used in applications ranging from power plants with integrated carbon capture and storage (Gładysz and Ziębik, 2015), and membrane-based carbon capture and storage (Troy et al., 2016) through to iron and steel production (Olmez et al., 2016), perfume production (Martinez-Guido et al., 2016), bio-oil production from fast pyrolysis and hydrothermal liquefaction of oil palm empty fruit bunch (Chan et al., 2016), to facade-systems of industrial buildings (Kovacic et al., 2016). For assessing the environmental impact of cement production, Mikulčić et al. (2016c) employed emergy and ecological footprint analysis to analyze several cement manufacturing processes, and showed the advantages of relying on multiple environmental indicators as these provide a better overview of the sustainability of cement production. An integrated approach to the sustainable development of energy, water and environment systems was developed for benchmarking the performance of cities (Kilkis, 2015; Kilkis, 2016a), airports (Kilkis and Kilkis, 2016), and innovation systems in different countries (Kilkis, 2016b). The results of case studies demonstrated that the integrated approach can be used by managers and governmental officials to coordinate strategies for achieving better city planning, increased social welfare, improvements in environmental quality and reductions of carbon dioxide emissions.

Air pollution in the Moravian-Silesian Region of the Czech Republic, heavily polluted by dust particles, was investigated by Sýkorová et al. (2017). At ten different sites, the authors monitored the atmospheric concentrations of heavy metals. The study demonstrated that chromium, manganese, iron and zinc mostly accumulate in dust particles with a diameter greater than $1.60 \mu \mathrm{m}$ while lead, cadmium and antimony are found mainly in particles smaller than $0.95 \mu \mathrm{m}$. Gaseous emissions and air pollution caused by power generation in Kosovo, were studied by Bekteshi et al. (2015). The results indicated that a significant reduction of air pollutants can be achieved if the power production sector turns to environmentally friendly energy sources. The continuation of the research by the same author, on heavy metal contamination, can be found in Section 3 of this SV.

Using waste byproducts from one industrial sector as a resource in other sectors was studied by different research groups. Wzorek and Tańczuk (2015) analyzed the production of biofuels from sewage sludge and found that it can be profitable under certain economic conditions. The application of waste ceramic dust as a replacement for cement in lime-cement plasters was considered by Kočí et al. (2016) who concluded that it is an environmentalfriendly and energy-efficient solution for the utilization of ceramic waste. The handling of fly ash from municipal solid waste incinerator was investigated by Hartmann et al. (2015), and showed that the incinerator fly ash needs to be carefully and responsibly handled, due to the hazardous content in it. The use of steel slag in road construction was investigated by Ferreira et al. (2016). Using life cycle assessment, it was shown that environmental benefits could be obtained if the steel slag was utilized as coarse aggregate in road pavements. Synthetic gas production from glycerol, a byproduct of biodiesel production, was studied by Tamosiunas et al. (2016) who found that, by using a thermochemical treatment method, glycerol could be effectively converted into synthetic gas with a high content of hydrogen and carbon monoxide.

Solid waste management and recycling were among the topics studied most extensively. The response of a waste management system to the consequences of a natural disaster was analyzed by Tabata et al. (2016). The natural disaster can result in a significant increase of waste originating from household consumer durables, and the waste management system needs to be dimensioned so as to adequately respond to such events. An evaluation of the sustainability of waste management for the city of Niš in Serbia was performed by Stefanović et al. (2016). Taking local conditions into account, the most sustainable waste management system was found to combine composting of organic waste and recycling of inorganic waste.

\section{Research themes and areas represented in this Special Volume}

After the review process, 30 papers from SDEWES 2015 were selected for this SV. The main ideas of these papers that are among the best articles presented at the conference are briefly reviewed in the following subsections.

\subsection{Energy issues}

Papers reviewed in this subsection illustrated the complexity of the current issues of energy systems including interlinked roles of fossil and renewable energy resources, carbon dioxide reduction and rational energy use in various sectors of the economy. 
Offshore oil production in ultra-deepwater oil fields involves oil and gas processing in Floating Production Storage and Offloading rigs, whose topside facilities are limited in terms of weight and footprint of (i.e., area required for) equipment. Low energy demand and low $\mathrm{CO}_{2}$ emission from the rigs are also desired. When the associated natural gas shows a high carbon dioxide content and gas to oil ratio is high, stringent constraints are imposed on upstream gas processing technologies. The contribution by Araújo et al. (in this volume) evaluated $\mathrm{CO}_{2}$ separation alternatives applicable to this challenging scenario in terms of technical, economic and environmental aspects, considering early enhanced oil recovery as the destination of carbon dioxide (which is injected back to oil reservoir). The Brazilian Pre-Salt fields (gas production of 6 millions $\mathrm{m}^{3}$ per day) are used as case study and the set of studied $\mathrm{CO}_{2}$ separation technologies encompasses membrane permeation, chemical absorption with aqueous methyl diethanolamine and piperazine, physical absorption with propylene carbonate and hybrid variants: physical absorption and membranes, membranes and chemical absorption, and two stages membrane. Using process simulation and costing tools, the authors found that membrane permeation is a solution with small footprint but chemical absorption - despite its large footprint - turns out to be the preferred technology option. It exhibits the lowest hydrocarbon losses and the lowest specific electricity consumption, lowest life-cycle costs and the lowest carbon dioxide emission per unit mass of injected carbon dioxide.

Sustainability of biomass production in Austria was investigated in the contribution by Maier et al. (in this volume). The authors developed a methodology to evaluate potentials of biomass integration in agricultural processes through replacing all parts of their life cycles by alternative processes characterized by low ecological impact. Impact evaluation was carried out using so-called Sustainable Process Index (SPI; Narodoslawsky, 2015) which accumulates the total resource use of a full life cycle of a process chain in an equivalent value of land area. Current typical agricultural cropping processes could be made more sustainable if heavy-footprint measures were replaced by those with smaller impacts in natural cycles.

As an example of application of SPI-based methodology, production of maize grain was evaluated to find out the ecological hotspots. "Business as usual" conventional farming practice was compared with ecological/organic farming practice. The evaluation results confirmed that fossil fuel consumption and application of mineral fertilizers along with pesticides are the main ecological hotspots of farming practices. The bandwidth of the values of ecological footprint was 24,731 to $10,690 \mathrm{~m}^{2}$, and that of carbon footprint was 88.5 to $22.6 \mathrm{~kg} \mathrm{CO} 2$ equivalent, per $1 \mathrm{t}$ maize grain production. The shift from conventional farming practice to organic farming and use of biogas as fuel could potentially reduce the ecological footprint by $22 \%-57 \%$ while the reduction potential in carbon footprint ranged from $38 \%$ to $74 \%$. The assessment results indicate that a shift from conventional farming practices towards organic farming and the use of renewable energy sources have a huge potential to achieve a more sustainable agriculture and strengthen a regionally based economy. It can also be seen that SPI footprint methodology is quite effective in locating ecological hotspots and finding an alternate environment-friendly solution in the life cycle of a process.

In the context of renewable energy, biodiesel production is a strategically important issue. In the paper by Hájek et al. (in this volume), the reactions and separations conditions for the transesterification of rapeseed oil by butanol under potassium hydroxide as a catalyst were described. The influence of reaction temperature and time, the amount of catalyst, the molar ratio of butanol to oil and the method of oil addition to butanol on the butanolysis process was studied. On the basis of experimental data analyzed by multi-linear regression, statistical models were established to describe the dependency of glycerides content in the product (a mixture of butyl esters of higher fatty acids) on the reaction conditions. Tests of transesterification stopping by neutralization of the catalyst were carried out with both a strong and weak acid added to whole reaction mixture. The advantage of strong acid is a very fast separation and a zero content of potassium and free glycerol, nevertheless a high acid number $(1.7-4.5 \mathrm{mg} / \mathrm{kg})$. In the case of weak acid (gas carbon dioxide), the acid number is less than $0.5 \mathrm{mg} /$ $\mathrm{kg}$, but the separation time is longer. The separation can be sped up by the addition of a small amount of water to the reaction mixture after the reaction and removal of butanol; this also reduces the content of potassium (10 times) and free glycerol ( 4 times) in the ester phase compared to the separation without water.

Kocík et al. (in this volume) studied the activity/selectivity of mesoporous silica based materials loaded with various types of active species in the esterification of tall oil free fatty acids. The metals such as aluminium, molybdenum, gallium, zinc, and their combinations were impregnated on the mesoporous silica, which was tested in esterification reaction. All the catalysts preserved its tall oil free fatty conversion in the first and the second catalytic cycles. However, while only insignificant amount of gallium or molybdenum was lost from the solid catalyst into the liquid phase, zinc leached from every studied solid catalyst. Gallium impregnated on mesoporous silica exhibited higher acidity and higher tall oil free fatty acids conversion in the first catalytic cycle, but its value was not preserved in the second catalytic test. This represents the most critical aspect in the reaction and it has to be improved in future.

Reflecting the current policies designed to reduce $\mathrm{CO}_{2}$ emissions, some papers were devoted to rational energy use and emission reduction in energy-intensive industries. Focusing on the production of stainless steel, the paper by Gajic et al. (in this volume) presented an integrated production and electricity optimization system that can help the melt shop, where scrap is melted, to adjust its production schedule to fluctuating electricity prices and thus lower its costs. An existing production scheduling optimization system based on a continuous-time mixed-integer linear programming model has been further developed to account for electricity costs as well. It deploys an intelligent heuristics to decompose the overall optimization problem into several subproblems of smaller size in order to achieve faster and more robust solution. The electricity-aware optimization system has been successfully tested and implemented in a melt shop where it managed to reduce electricity costs by around $3 \%$. At the same time, the system has improved coordination between different production stages, and thus made the entire melt shop more flexible and responsive to unexpected events. The system has also been recognized as a very useful tool for running various simulations, what-if analysis and business scenarios on the melt shop in order to identify bottlenecks and further increase its production rate.

The paper by Hassiba et al. (in this volume) addressed $\mathrm{CO}_{2}$ integration of industrial parks, i.e. the integration of $\mathrm{CO}_{2}$ sources, sequestration and utilization options between neighboring industrial plants to achieve required emissions reductions at minimum cost. The work made use of the recently proposed $\mathrm{CO}_{2}$ integration approach (Gharaie et al., 2013) to explore carbon management options across an industrial park together with energy integration approaches to (1) minimize net energy demand of the industrial park and therefore cut fuel and corresponding emissions, and (2) explore synergies available from utilizing excess process heat to provide low-cost, emissions free heat and power sources for energy intensive carbon capture and compression costs. The proposed approach combining methods for $\mathrm{CO}_{2}$ and heat integration was 
applied to an illustrative example of an industrial park containing a set of process plants of the type observed in Mesaieed Industrial City in Qatar: a methanol plant, refinery, fertilizer complex, power plant and central utility system which consisted of a gas turbine, Heat Recovery Steam Generator, boiler, and six steam turbines (four backpressure and two condensing ones). The utility system was assumed to export $10 \mathrm{MW}$ of electricity to the grid, and the city - to import $30 \mathrm{MW}$ from the power plant. $\mathrm{CO}_{2}$ reduction by Carbon Capture and Storage was considered at a level of $15 \%$, and by utilizing integration options, an additional $1.5 \%$ reduction could be obtained. Moreover: the integration of excess heat reduced the annual costs for some plants by more than 5 million USD per year.

Energy savings obtainable on the level of an entire sector of national economy (in Albania) were studied in the paper by Spahiu et al. (in this volume). The attention was focused on the water sector. The paper presented the hypothesis that performing energy audits at water sector paves the way for saving energy, money and water in water companies. The importance of energy audits was illustrated by a case study of Water Supply and Sewerage Company of Tirana, where opportunities had been identified for significant energy and economic savings by using energy efficient motors, compensating power factor and using variable speed drives on pumping systems. Based on life cycle analysis, the paper highlighted the implementation of proposed energy efficiency measures to ensure: reduction of energy consumption from $15 \%$ up to $37 \%$, reduction of $\mathrm{CO}_{2}$ emission, improvement of financial sustainability of the company, better management of water resources, etc.

Energy use and the associated $\mathrm{CO}_{2}$ emissions in the transport sector were discussed in a number of papers. In Finland, rationalization of long-distance timber transportation by road freight gained new momentum in 2013 when the Ministry of Transport and Communications of Finland increased the maximum mass to $76 \mathrm{t}$ for larger and heavier vehicle combinations equipped with nine axles, e.g., four axles in a truck and five axles in a trailer. The study by Palander (in this volume) assessed the environmental impacts of the raised mass limits, that is, the shift to larger and heavier vehicles, on emission efficiency using the synchronized calculation method. The method took account of two factors: load mass and the migration of loads to heavier vehicles. The method was successfully tested by calculating emission efficiency after the shortterm adaptation process, that is, a year after the mass limits had been raised. Calculations were made for four mass limits $(60,64,68$ and $76 \mathrm{t}$ ). Based on Enterprise Resource Planning data from Stora Enso Company, efficiency of $\mathrm{CO}_{2}$ emissions (measured in relation to trip) increased $15.8 \%$ for $76 \mathrm{t}$ vehicles and $\mathrm{CO}_{2}$ emissions were reduced $6.2 \%$ to $42.8 \mathrm{~g} / \mathrm{tkm}$. The results showed that increase in maximum vehicle mass yields cleaner wood procurement chain in pulp production process. The study also confirmed that the synchronized calculation method can be used in real-world transport systems and local wood supply chains to simulate and evaluate emission efficiencies of larger and heavier vehicle combinations.

Current trends in the development of electrically driven road vehicles indicate increasing role of lithium-ion batteries in the transport sector. Emerging applications of such batteries in hybrid electric vehicles, plugin hybrid electric vehicles, and also in grid support are becoming more and more power demanding. The increase in power capability rates of lithium-ion batteries at charging and discharging raises safety and reliability concerns and requires thermal management of the entire battery system. Thus, thermal modelling of lithium-ion battery cells and battery packs is gaining importance. Recent research initiated by Barsoukov et al. (2002) proposed electrothermal impedance spectroscopy (ETIS) as a novel and non-destructive method of characterizing the thermal properties of batteries by defining frequency dependent thermal impedance. It has already proved useful, but can be still improved in terms of e.g. accuracy and measurement time and it has a potential to be extended to new applications. A review presented in the paper by Swierczynski et al. (in this volume) indicates that the ETIS is a promising, non-destructive, simple and cost-efficient method for thermal characterization of batteries. After systematizing the state of knowledge about electrothermal impedance spectroscopy and presenting different measurement methods, their application to a high-power lithium battery cell is outlined and finally the prospects of ETIS measurement are discussed.

Several contributions reflected the prominent role of universities in developing new energy-saving technologies, providing examples of efficient energy management in large organizations and promoting energy awareness among societies.

Since 2011, South East European University (SEEU) in Macedonia is under realization of a Low Emission University Campus through the implementation of a Climate Action Plan (CAP) aimed at final carbon neutrality and energy efficiency. Distributed Energy Resources of SEEU Campus with renewable energy sources (solar and biomass) and the Energy Management System with implementation of Smart Technologies represent a small-scale energy system and hands-on laboratory for switching to a new sustainable paradigm. The paper by Iljazi et al. (in this volume) reported on the investigation in Small-scale University Campus Power Supply Network, SEEU Microgrid, that can be used as a bottom-up approach in realization of sustainable energy strategy for energy systems. Implementation of smart technologies will help to balance power generation to demand, to reduce the potential for blackouts and to monitoring power quality. This vision will enable also the realization of the objectives in terms of energy security and sustainability with economic and social impact. With the broad set of operational issues being addressed, the Real Lab provides foundation in the major features of global energy issues, sustainable energy technologies and their interactions with economics, the environment and policy. Apart from presenting the university campus with integrated energy supply as a real sustainable laboratory, the paper provides a summary of measured data with implementation of smart technologies and conclusions for future activities to balance power generation with demand and to enhance energy efficiency, security and power quality.

Living lab facilities are increasingly representing a mainstream strategy to monitor university campuses energy consumption patterns, support the relative decision-making processes and communicate the energy performance to national and international ranking systems. However, there is a gap between data monitoring strategies and effective energy reduction policies. This is mainly due to the inadequacy of current campuses' sustainability assessment tools, which does not provide a specific consumption thresholds according to universities' context, functions hosted and typologies. In order to overcome this gap, the paper by Sonetti et al. (in this volume) analyzed the different energy consumption collection methods and profiles in a span of four years' time both at the Politecnico di Torino (Italy) and Hokkaido University (Japan), similar for weather context and urban scale. A partial regression analysis on these data split down for departments confirmed 5 different clusters of homogeneous consumption ranges according to the activities of departments hosted by each building. This energy cluster approach can significantly enhance the accountability and comparability of different and complex campuses' energy profiles, contributing to a better evaluation of universities' energy performances.

Clustering principles based on exergy, that is, quantification of the quality of energy, can assist in attaining a more efficient and cleaner energy supply structure. The paper by Kilkiş et al. (in this volume) analyzed two building clusters in campus areas of KTH Royal Institute of Technology (in Stockholm, Sweden) based on a 
stepwise approach with four steps according to the Rational Exergy Management Model. The clusters involved $8 \mathrm{KTH}$ buildings and 10 additional ones in the Albano district of Stockholm that is a former industrial site and will become a joint campus area. The energy supply for the campus and urban vicinity includes a combined heat and power plant with district heating and cooling. In this context, the energy and exergy profiles of the building clusters were compared and the level of exergy match (in both demand and supply of exergy) in the energy system was analyzed. Four scenarios were then devised, which involve energy savings and different shares of various supply options. These include a new biofuel unit, seawater heat pumps, large scale aquifer storage for thermal energy, heat supply from solar collectors, and electricity and heat from photovoltaic thermal arrays. The present case and four scenarios were found to have differentiated exergy matches. The scenarios indicated that annual savings of 16 GWh energy, 9.6 GWh exergy, and 2663 tons of carbon dioxide emissions are possible.

The paper by Al-Shemmeri and Naylor (in this volume) presented the findings of a study on students' energy awareness conducted at a further education college in the Midlands, United Kingdom. The focus was on learner involvement with energy saving and environmental projects. Previous research had shown that within the domestic environment participants socio-economic characteristics and environmental attitudes are linked to their predisposition to participate in energy conservation measures. The objective of the study was to examine whether those same principles could be applied to teenagers in an educational setting. This analysis was based on data collected in questionnaires from 1200 students, primarily aged $16-18$ years. When assessing the relative importance of socio-economic demographics and environmental attitudes, within the student body, the strength of environmental awareness exhibited consistently greater significance with the former, rather than the latter. Results indicated that energy saving behavior was distributed across several demographics, with the current level of study, social altruism - by commitments to communities or charities, and parental influence - pre-installation of renewable technology in the family home, prompting students' views and opinions. This research results could be used as the basis for targeting those student groups that currently exhibit a lower than average commitment to energy conservation.

\subsection{Water issues}

Among papers dealing with water use and wastewater treatment, those devoted to the planning and management of water resources in water-stressed regions constituted a major group.

In densely populated arid and semi-arid areas, rain and dew water can have a significant impact as new sources of potable water. A team of Indian and French authors demonstrated in their contribution (Sharan et al., in this volume) that atmospheric moisture can be harvested and processed into safe drinking water comparable in quality and price to reverse-osmosis processed water available in the market. The paper described the construction and operation of a water production plant in the locality of Kothara (Gujarat State, northwest India) where rain and dew are collected. For dew collection, special condenser architecture (ridges) was designed using Computational Fluid Dynamics simulation and improved condensing surfaces were developed. Using dew yield estimates obtained by simulation based on the meteorological data, an economic analysis was carried out. It was found that water passively harvested from atmospheric moisture may be cheaper than that obtained by reverse osmosis. As passive harvest also avoids adverse effects on the environment, dew and rain resources can be regarded as a viable supplementary supply of potable water in water-stressed environment.

In a context of climate change and increasing need of fresh water in the world, the availability of robust spatial information on evapotranspiration from multiple land cover types is deemed critical for several applications in agriculture and water balance studies. Liaqat and Choi (in this volume) utilized the Surface Energy Balance System (SEBS) model to estimate actual evapotranspiration and water scarcity footprints under the complex landscape of Korean peninsula where vegetation practices and local environmental conditions are widely differentiated. Using ModerateResolution Imaging Spectroradiometer (MRIS) satellite data for the full hydrological year of 2012, the modelled evapotranspiration was compared with flux tower measurements obtained from a subhumid cropland and temperate forest sites for the accuracy assessment. This accuracy comparison at daily scale indicated good agreement at both types (cropland, forest) of observation sites. Furthermore, the monthly aggregated evapotranspiration from SEBS showed more promising results than those of obtained from MRIS-based readymade global evapotranspiration product (known as MOD16), when both products were compared with flux tower measurements. Water stress mapping at regional and monthly scale also revealed strong contrast between the two approaches. Using estimated evapotranspiration from SEBS, the highest mean water stress was observed for land use areas associated with evergreen forest and under sparsely vegetation condition while using MOD16, a lower extreme mean water stress was found in cropland regions. It was argued that MOD16 algorithm needs improvement as it is not yet strong enough to capture the various hydro-meteorological characteristics with high accuracy. Overall, the developed water stress map has also a strong relationship with gross primary production (of organic compounds from atmospheric or aqueous carbon dioxide), and a combination of both could be useful to improve the understanding of net ecosystem exchange.

Interactions between water use and energy supply attracted the attention of many author teams. In the paper by Brandoni and Bošnjaković (in this volume), water and energy nexus in large scale was studied for Sub-Saharan Africa where climate change, population growth and rapidly increasing urbanization severely threaten water quantity and quality. Treating wastewater is necessary to preserve the water bodies, and reusing treated wastewater appears a viable option that could help to address future water challenges. In areas already suffering from energy poverty, the main barrier to wastewater treatment is the high electricity demand of most facilities. This work aimed to assess the benefits of integrating renewable energy technologies to satisfy the energy needs of a wastewater treatment facility based on a conventional activated sludge system, and also considered the case of including a membrane bioreactor so treated wastewater can be reused for irrigation. Using HOMER, a software tool specifically developed for optimal analysis of hybrid micro-generation systems (Lambert et al., 2006), the optimal combination of renewable energy technologies was identified for these facilities when located in a specific water-stressed area of Sub-Saharan Africa and the costeffectiveness solutions were assessed. The analysis showed investment in renewable technologies is cost-effective when the true cost of electricity or average days of power outages per year are considered. Integration of photovoltaic panels, a wind turbine and internal combustion engine fuelled by biogas produced by anaerobic digestion can cover between $33 \%$ and $55 \%$ of the electricity demand of the basic wastewater facility, at a levelised cost of energy lower than the true cost of electricity. In the case of water reuse, the techno-economically viable solutions identified by HOMER can cover $13 \%$ of energy needs. The proposed solutions could also provide a large contribution to socio-political security, in both domestic and cross-border contexts. 
Water and energy nexus in local scale was the subject of the contribution by Kollmann et al. (in this volume). While the main purpose of wastewater treatment plants concerns water pollution control, such plants can be interesting from an energy point of view, as they have high potentials for heat generation beyond common digester gas combustion. Focusing on a case study of the Austrian small town Freistadt (population 7500) located in Upper Austria close to the Austrian-Czech border, it was shown that the available surplus energy of the wastewater treatment plant could be fed into public energy distribution grids to supply external consumers. Different software tools were applied to support optimised integration: existing and future energy demands of different spatial units were analyzed by the Energy Zone Mapping (based on the Geographical Information System). Process Network Synthesis was applied to perform optimization on an economical level, and using Sustainable Process Index, the ecological footprint of the regarded technologies was assessed. Besides describing the theoretical background and the practical application of the tools, the paper presented the results obtained from the case study. The investigations gave clear evidence, that significant amounts of heat could be supplied to the adjacent consumers at competitive costs and with considerable ecological benefit. Consequently, the wastewater treatment plant could provide local energy planners with an "unexpected" and locally available renewable source of energy.

In the industrial context, wastewater treatment technologies are strategically important to many companies. In plating processes, electrodialysis had been already applied for wastewater treatment and metal recovery, however, depending on the operational settings, this technology sometimes presented loss of process efficiency. The work of Benvenuti et al. (in this volume) was aimed at determining the operational parameters of electrodialysis necessary to scale up the process and to close the water loop in the nickel electroplating industry. The evaluation in bench scale using synthetic effluents allowed to determine limiting current density, stack configuration and desired characteristics for the solutions produced by electrodialysis. The parameters defined in these tests were used in industrial-scale electrodialysis, more specifically in a continuous treatment process connected to an industrial rinse water line of nickel plating. The operation in industrial scale confirmed that the quality of obtained solutions is sufficient for reuse in the nickel plating process. The reuse of concentrated stream allowed chemicals saving around $20 \%$ for nickel plating bath. The diluted solution reached conditions similar to tap water; allowing the reuse of this solution as rinse water and reducing by $90 \%$ the volume of effluent sent to the wastewater treatment plant. The reused solutions did not affect the visual quality of the nickel deposit and its protective properties. With near zero pollutants emissions, electrodialysis treatment may be of significant interest to the electroplating industry, providing a closed-loop galvanic process for reducing environmental and economic burdens.

\subsection{Environmental engineering and management}

In this section papers devoted to environmental engineering and management with three thematic subfields are included: a holistic approach to specific industrial activities and their environmental impact; technologies for waste minimization, upgrading or neutralization, and for environmental monitoring; solid waste collection and management, and recycling.

A method based on Life Cycle Assessment to reduce and simplify the decision-making process and to identify the best available techniques of a product was discussed in the contribution by Laso et al. (in this volume). The method facilitates the selection of a technical alternative from an environmental point of view and the reduction of emission levels and the consumption of energy and primary resources. This is done in the following four steps: (i) the identification of the current techniques of a specific product, (ii) the application of a life cycle assessment to determine the hot spots, (iii) the proposal of the best available techniques and (iv) the development of a best available techniques reference document (step not implemented in our case study). The Cantabrian anchovy canning industry was selected as a case study (in which, however, step (iv) was not implemented) due to the importance of this sector from economic, social and touristic points of view. An entire LCA of one can of anchovies in extra virgin olive oil was conducted. The results indicated that the hot spots of the life cycle were the production of aluminium cans (for packaging) and extra virgin olive oil and the management of the packaging waste. According to these results, the study proposed several improvements, such as packaging recycling, use of a recovery oil system by recirculation to prevent oil loss, and minimization of the use of water, energy and detergents.

Currently, a huge amount of cargo is transported with maritime and road transport throughout the world. The majority of it is in cargo containers, which results in high environmental impacts caused by the transport and the manufacturing of the containers, such as depletion due to the large quantities of material used for the production of the approximately 18.6 million cargo containers in use globally. Another environmental impact is carbon emissions released in the production and use phases. One possible solution for more sustainable cargo transport is environmentally friendlier cargo containers, made according to eco-design principles. They are lighter, produced from less material with smaller environmental impact throughout their life cycle. The paper by Obrecht and Knez (in this volume) assessed the environmental impacts of a standard 20-foot cargo container with a simplified LCA study, focusing especially on GHGs emissions. It reveals that up to $67 \%$ of all greenhouse gas emissions are related to material supply. A solution for environmentally friendlier cargo containers was seen in an ecodesign dematerialisation strategy, with particular emphasis on the use of material and the production phase, but without compromising its performance. Three different designs of cargo container walls were assessed from an environmental perspective. Comparative analysis has shown a difference of approximately $15 \%$ in material use when comparing cargo containers with the highest and lowest impacts.

Lactic acid produced from renewable sources is used for the production of polylactic acid and biodegradable polymers. However, large-scale production of biodegradable polymers and other large-tonnage lactic acid-based chemical products is limited by the difficulties of waste generation and low productivity. To overcome these problems, Kozlovskiy et al. (in this volume) developed a method of ammonium lactate production from carbohydrates using a membrane bioreactor and semicontinuous cultivation with controlled parameters. During 130 operation cycles, the average specific productivity of the bench-scale biochemical reactor for ammonium lactate was $56 \mathrm{~g} /(\mathrm{L} \cdot \mathrm{h})$, which was an order of magnitude higher than that attainable in traditional industrial processes. To significantly reduce the waste produced in the form of calcium sulfate, lactic acid derivatives were isolated from the butyl lactate intermediate without calcium sulfate formation. A method for the production of other large-volume chemicals such as propylene glycol was also developed through hydrogenation of butyl lactate on a copper oxide-silica catalyst whereby $99 \%$ yield and $99 \%$ selectivity for propylene glycol formation were obtained. The results of bench-scale tests pave the way for the development of competitive industrial processes for the production of biodegradable polymers and large-tonnage chemical products based on renewable raw materials. 
Technologies for upgrading or abatement of various kinds of solid waste as well as of liquid and gaseous effluents were studied in a number of papers. Large amounts of potassium and silicon contained in biomass ashes can substitute for equivalent-quality raw materials to make agricultural or industrial products. In the study by Wang et al. (in this volume), a multi-step extracting method for straw/woody biomass ashes was developed to enhance the efficiency of their utilization. Different products obtained from biomass ashes (generated at $500{ }^{\circ} \mathrm{C}$ ) were characterized by X-ray diffraction and X-ray fluorescence and in addition, the slagging/ fouling tendency of three kinds of biomass ashes was evaluated and compared with that of fifty three kinds of biomass ashes described in the references. In the extractive products from biomass ashes, potassium mainly exists as potassium chlorides and sulfates, such as $\mathrm{KCl}, \mathrm{K}_{2} \mathrm{SO}_{4}, \mathrm{KNaSO}_{4}$ and $\mathrm{KNa}_{3}\left(\mathrm{SO}_{4}\right)_{2}$. More potassium salts could be recycled from ashes if the burning temperature of biomass was decreased. The initial extraction ratio of $64.04 \%$ for cotton straw ashes is larger than that of wheat straw ashes and sawdust ashes. The order in the total accumulated extracting ratio of potassium from ashes is cotton straw $>$ wheat straw $>$ sawdust. Regarding the risk of deposition and corrosion if the biomass is burned in boilers, it is high for wheat straw, and somewhat lower for cotton straw and sawdust. Overall, the results show that salt extraction could be suggested as a feasible and sustainable utilization option for biomass solid wastes.

Winery effluents are substantial sources for the recovery of antioxidant compounds, namely polyphenols and polysaccharides. In the study by Giacobbo et al. (in this volume), aqueous extraction associated with microfiltration was used as a pretreatment for the recovery, by membrane processes, of polyphenols and polysaccharides present in effluents (wine lees) from the first racking of red winemaking. The study was carried out in total recirculation mode using a flat-sheet membrane and in concentration mode using a hollow fiber membrane. Although the most diluted permeates presented lower contents of polyphenols and polysaccharides, the solutes recovery did not follow this behavior. Higher dilution factors of the effluent resulted in higher permeate fluxes as well as in higher polyphenols recovery. At the best conditions, a solution diluted $50 \mathrm{~V} / \mathrm{V}$ followed by microfiltration led to the achievement of a limpid permeate, representing a recovery of $1 \mathrm{~g}$ of polyphenols and $1 \mathrm{~g}$ of polysaccharides per liter of raw effluent.

Chandrashekhar and Pandey (in this volume) studied an integrated biochemical process for the treatment of stationary gaseous emissions containing nitric oxide. The process involves absorption of nitric oxide in a solution of ferrous nitrilotriacetate followed by regeneration of the solution by microbial reduction of nitrosyl adduct of ferrous nitrilotriacetate and ferric nitrilotriacetate present in the solution generated during absorption. A laboratory-scale up-flow anaerobic biofilm reactor using polyurethane foam cubes as a support matrix for biofilm was employed for the treatment of $20 \mathrm{mM}$ ferrous nitrilotriacetate solution scrubbed with synthetic nitric oxide gas mixture. The biofilm was developed by fed-batch operation for 30 days by using enriched bacterial culture capable of reducing nitrosyl adduct and ferric nitrilotriacetate using ethanol as an organic electron donor. Under steady-state conditions, the nitrosyl adduct reduction efficiency exceeded $90 \%$ at a loading rate of $0.24 \mathrm{mM} /(\mathrm{L} \cdot \mathrm{h})$ while ferric nitrilotriacetate reduction efficiency was $15-20 \%$. The average biofilm thickness was about $550 \mu \mathrm{m}$, decreasing the porosity of the matrix. Reactor hydrodynamics was studied by tracer (methyl orange) experiments. The analysis based on residence time distribution theory involved axial dispersion flow model and tracer diffusion with linear adsorption inside the biofilm. Peclet number value of 28 was obtained allowing the plugflow assumption for the reactor model. The experimental profiles of the nitrosyl adduct reduction in the reactor were explained by using a kinetic model of first order reaction coupled with NO diffusion inside the biofilm.

The remediation of degraded surface soils in Europe is a major challenge due to large land areas where a mixture of contaminants is detected and no biologically active topsoil is present. In order to restore degraded sites with soil organic matter and stabile plant cover, the use of sewage sludge has been proposed, but the applications are restricted by the requirements of the European Union's directives on chemical quality of the sewage sludge. Grobelak et al. (in this volume) performed a study to investigate the effect of a one-time amendment of sewage sludge with low metal content on a barren and contaminated soil. The field experiment was conducted in the contaminated area near a zinc smelter where poor soil fertility and high concentration of cadmium, zinc and lead had been detected. A single application of sewage sludge from food industry was made and forest species of pine, spruce and oak were used for phytoremediation. The application of sewage sludge proved beneficial for the development of plant cover and after five years, a significant increase in the biomass of trees (mainly spruce and pine) was achieved; moreover, in the amended plots, the spontaneous growth of various species of other plants was also observed. On control plots where no sewage sludge was applied, the planted trees gradually withered away during the same period. The nutrients provided in the sewage sludge were effectively utilized by the plants and the sludge also contributed to soil organic matter leading to increased the water holding capacity in the test plots. Compared to the control plots, the content of macroelements and carbon in soil was still higher at the end of the five-year study. As the bioavailable macroelements in sewage sludge were gradually released and fully used by plants to stimulate their growth, no leaching or run-off into groundwater was detected. The content of cadmium, zinc and lead in plant biomass was much lower compared to the biomass from untreated pots. As the obtained data support the use of good quality sewage sludge for remediation of contaminated and barren soils, large scale trials will follow on various degraded soil types.

Reliable and systematic environmental monitoring is a prerequisite for efficient control of occupational hazards and management of the risk of ecological devastation of the natural environment. Bekteshi et al. (in this volume) presented the results of radon concentration measurements and radiation exposure levels of underground mine in Trepça, Kosovo where lead, zinc and copper ores are exploited. In order to assess the radiogenic hazards to mine workers, radon concentration measurements have been carried out in the selected locations of Trepça mine using commercial radon monitoring instruments. Results showed that the radioactivity from radon gas concentration in underground mine varied from 54 $\mathrm{Bq} / \mathrm{m}^{3}$ to $691 \mathrm{~Bq} / \mathrm{m}^{3}$. After analysing the radiation exposure doses of miners from radon and products of radon decay, the total annual effective doses were found to vary from $0.5 \mathrm{mSv} / \mathrm{y}$ to $6.2 \mathrm{mSv} / \mathrm{y}$, that is, lower than the dose limits recommended by International Commission of Radiation Protection (ICRP, 2007). For comparison, the results of the study carried out at the same locations in 2010 were presented. It was found that five-year mining activities have generated pathways for radon gas flow, causing a decrease in the maximum values of radon concentration; however, the average values increased by about $10 \%$.

For monitoring the changes in environmental features in large land areas, airborne engineering is now enabling the construction of small automatic flying vehicles, so called multicopters or flying drones. Anweiler and Piwowarski (in this volume) studied the design and manufacture of low-cost, low weight quadcopter platform prototype for the purpose of environmental monitoring and research. A multirotor concept was created assuming executive 
functions such as hovering, environmental data acquisition and movements controlled by the Global Positioning System. On the basis of these assumptions, platform components were chosen including quadcopter frame, drives, electronics and software. The measurement capabilities of the vehicles for analytical agriculture were presented along with the discussion on their application capabilities, advantages and disadvantages. On the basis of the developed design, a prototype quadcopter platform was built and test flights were conducted. As a result of the whole process, the platform that is able to accomplish the assumed tasks was created. The manufacturing cost of the drone prototype was below 500 EUR and the mass was less than $750 \mathrm{~g}$.

Solid waste collection and management, and recycling are problem areas of vital importance to many industries as well as to regions and communities. Utilization of the quality-upgraded waste paper in the manufacture of paper and board will reduce the wood consumption and pulping energy. While the optical property of the fibers from recycled old newspaper is very poor, insitu calcium carbonate formation on those fibers by injecting carbon dioxide to the mixed slurry of those pulp and calcium oxide can improve their brightness. In the contribution by Seo et al.(in this volume), upgrading of recycled old newspaper to substitute more expensive wood fiber furnish, such as recycled old magazines, was successfully demonstrated. This study showed that the in-situ calcium carbonate formation process improved the optical quality of the recycled old newspaper by covering colored impurities with newly formed calcium carbonate, and improved calcium carbonate retention in papermaking process by attaching them to fibers. The strength reduction caused by the presence of newly formed calcium carbonate in the paper was counteracted by adding strength agent. High ash retention at high ash content under the strong turbulence in the modern paper mill was achieved by the application of the in-situ calcium carbonate formation method. The quality improvement of recycled fibers and cost saving in the manufacture of duplex paperboard were demonstrated in the mill trial.

In Brazil, $51.4 \%$ of municipal solid waste is composed of organic matter; however, composting is rarely used as a treatment technology. In 2008, only $3.8 \%$ of Brazilian municipalities had access to composting plants and about $11.6 \%$ of municipalities destined the municipal solid waste to recycling plants, thus processing only $1.4 \%$ of total waste generated. Recycling and composting are key components of municipalities' programs to reduce the environmental impact of waste management. The contribution by Deus et al. (in this volume) aimed to evaluate the environmental impact of inserting a recycling, composting and integrated program in the region of Sao Paulo State through the Waste Reduction Model method of simulating emissions of greenhouse gases (carbon dioxide equivalent and carbon equivalent) and energy use. The results showed that recycling and composting can decrease the emission of greenhouse gases, reducing carbon dioxide and carbon equivalents, and promote energy savings. The best result was offered by the integration of these techniques, allowing to reduce $78.8 \%$ of carbon dioxide and carbon equivalents and to avoid energy expenditure of $490.9 \%$ versus baseline scenario. The outcomes of the study can be used by municipalities creating waste management scenarios as a tool for planning and decision making to reach targets set by national solid waste policies.

The lack of suitable sites and the high cost of waste treatment have persuaded many Brazilian municipalities to implement a policy for integrated waste management, which includes measures such as, source reduction, reuse, recycling, composting and final disposal in landfill. The study by Oliveira et al. (in this volume) examined the alternatives for composting of the organic waste generated in the city of Bauru (São Paulo State). As no composting plant is presently available in Bauru, environmental impacts were analyzed of seven scenarios: current situation, in which all organic waste is disposed at the landfill; dispatch of the organic waste generated in the city to the closest municipality having a composting plant; construction of a composting plant in Bauru; use of home composting for $10 \%, 25 \%, 60 \%$ and $90 \%$ of total organic waste. Following literature review and data collection among the companies responsible for the waste management in the municipality, Life Cycle Assessment was performed of the scenarios through the software IWM-2 for the Life Cycle Inventory and Recipe2008 conversion factors for the following impact categories: climate change, ozone depletion, particulate matter formation, and human and freshwater toxicity. The results showed that to control greenhouse gas emissions derived from waste transportation and collection, home composting must be combined with a reduction in the organic waste collection days. Compared with composting plants, home composting has a greater potential to reduce carbon dioxide equivalent emissions per mass of waste composted. The use of transfer station can have a positive effect on composting plants that are located in other municipalities.

\section{Concluding remarks}

This Special Volume of the Journal of Cleaner Production, dedicated to the 10th SDEWES Conference, gave an overview of topics related to sustainable development and cleaner production. The authors of this article are confident the selected papers and addressed issues will substantially contribute to and increase the knowledge body published in the Journal of Cleaner Production and will be of interest to its readers.

From approximately 550 contributions presented at the SDEWES 2015 Conference, 30 papers were selected for this SV. The selected papers describe recent advances, and provide insights into future development, in three main fields that are of strategic importance to the sustainable development: energy issues, water issues, environmental engineering and management. The contents of the selected contributions are reviewed in Section 3, the main part of this article, however, only a brief overlook of the wealth of research ideas is given there. Nevertheless, throughout all of these studies two important messages are emphasized. Firstly, sustainable development is a highly interdisciplinary topic, as it often involves interactions of different systems; and secondly, a holistic approach to sustainable development is needed to improve the resource efficiency of the combined energy, water and environment system. Therefore, the main message of the current SV is that sustainable development is a journey, not an endpoint, and this will require expanded and new efforts as humanity continue on its journey through time.

Future SDEWES Conferences will build upon the potential of presenting new practical experience and disseminating new knowledge on shaping the future by building upon the pillars of sustainability. Information on the upcoming events and other related activities can be found on the website of the International Centre for Sustainable Development of Energy, Water and Environment Systems (SDEWES Centre) at http://www.sdewes.org/.

\section{References}

Al-Shemmeri, T., Naylor, L., 2017. The Relative Importance of Socio-economic Groups and Pro-Environmental Attitudes Within a Student Population in an UK Further Educational Establishment (in this volume).

Ananpattarachai, J., Kajitvichyanukul, P., 2016. Enhancement of chromium removal efficiency on adsorption and photocatalytic reduction using a bio-catalyst, titania-impregnated chitosan/xylan hybrid film. J. Clean. Prod 130, 126-136. Anweiler, S., Piwowarski, D., 2017. Multicopter Platform Prototype for Environmental Monitoring (in this volume).

Anzaldi, G., 2014. A holistic ICT solution to improve matching between supply and 
demand over the water supply distribution chain. J. Sustain. Dev. Energy Water Environ. Syst. 2, 362-375.

Araújo, O., Reis, A.C., de Medeiros, J.L., do Nascimento, J.F., Grava, W.M., Musse, A.P. 2017. Comparative Analysis of Separation Technologies for Processing Carbon Dioxide Rich Natural Gas in Ultra-deepwater Oil Fields (in this volume).

Baleta, J., Vujanović, M., Pachler, K., Duić, N., 2015. Numerical modeling of urea water based selective catalytic reduction for mitigation of NOx from transport sector. J. Clean. Prod. 88, 280-288.

Baleta, J., Mikulčić, H., Vujanović, M., Petranović, Z., Duić, N., 2016. Numerical simulation of urea based selective non-catalytic reduction deNOx process for industrial applications. Energy Convers. Manag. 125, 59-69.

Barsoukov, E., Jang, J.H., Lee, H., 2002. Thermal impedance spectroscopy for Li-ion batteries using heat-pulse response analysis. J. Power Sources 109, 313-320.

Beal, C.D., Gurung, T.R., Stewart, R.A., 2016. 2016. Modelling the impacts of water efficient technologies on energy intensive water systems in remote and isolated communities. Clean. Technol. Environ. Policy 18, 1713-1723.

Bekteshi, S., Kabashi, S., Ahmetaj, S., Šlaus, I., Zidanšek, A., Podrimqaku, K., Kastrati, S., 2015. Dynamic modeling of kosovo's electricity supply-demand, gaseous emissions and air pollution. J. Sustain. Dev. Energy Water Environ. Syst. 3, 303-314.

Bekteshi, S., Kabashi, S., Ahmetaj, S., Xhafa, B., Hodolli, G., Kadiri, S., Alijaj, F., Abdullahu, B., 2017. Radon Concentrations in Trepça Underground Mines; a Comparative Study (in this volume).

Benvenuti, T., Rodrigues, M.A.S., Bernardes, A.M., Zoppas-Ferreira, J., 2017. Closing the Loop in the Electroplating Industry by Electrodialysis (in this volume).

Bing, S.H., Hooi Hong, B., Loong Lam, H., Friedler, F., 2016. Synthesis of multiple biomass corridor via decomposition approach: a P-graph application. J. Clean. Prod. 130, 45-57.

Boldyryev, S., Mikulčić, H., Mohorović, Z., Vujanović, M., Krajačić, G., Duić, N., 2016. The improved heat integration of cement production under limited process conditions: a case study for Croatia. Appl. Therm. Eng. 105, 839-848.

Brandoni, C., Bošnjaković, B., 2017. HOMER Analysis of the Water and Renewable Energy Nexus for Water-stressed Urban Areas in Sub-Saharan Africa (in this volume).

Chan, Y.H., Tan, R.R., Yusup, S., Lam, H.L., Quitain, A.T., 2016. Comparative life cycle assessment (LCA) of bio-oil production from fast pyrolysis and hydrothermal liquefaction of oil palm empty fruit bunch (EFB). Clean. Technol. Environ. Policy 18, 1759-1768.

Chandrashekhar, B., Pandey, R.A., 2017. Experimental and Modelling Study of Treatment and Regeneration of Ferrous-nitrilotriacetate Solution Scrubbed With Nitric Oxide by an Up-flow Anaerobic Biofilm Reactor (in this volume).

Cheng, Z., Yang, J., Zhou, L., Liu, Y., Guo, Z., Wang, Q., 2016. Experimental study of commercial charcoal as alternative fuel for coke breeze in iron ore sintering process. Energy Convers. Manag. 125, 254-263.

Clyde, E.J., Champagne, P., Jamieson, H.E., Gormand, C., Sourial, J., 2016. The use of a passive treatment system for the mitigation of acid mine drainage at the Williams Brothers mine (California): pilot-scale study. J. Clean. Prod. 130, 116-125.

Colla, V., Branca, T.A., Rosito, F., Lucca, C., Padilla Vivass, B., Menendez Delmiro, V. 2016. Sustainable reverse osmosis application for wastewater treatment in the steel industry. J. Clean. Prod. 130, 103-115.

Degiuli, N., Catipović, I., Martić, I., Werner, A., Corić, V., 2017. Increase of ship fuel consumption due to the added resistance in waves. J. Sustain. Dev. Energy Water Environ. Syst. 5, 1-14.

Deus, R.M., Battistelle, R.G., Silva, G.H.R., 2017. Current and Future Environmental Impact of Household Solid Waste Management Scenarios for a Region of Brazil: Carbon Dioxide and Energy Analysis (in this volume).

Dias, M.A.P., Haddad Alves, A.S., Vianna, J.N.S., 2016. A pathway to energy and food security with biodiesel. J. Sustain. Dev. Energy Water Environ. Syst. 4, 242-261.

Dominković, D.F., Bačeković, I., Cosić, B., Krajačić, G., Pukšec, T., Duić, N., Markovska, N., 2016. Zero carbon energy system of South East Europe in 2050. Appl. Energy 184, 1517-1528.

Duic, N., Urbaniec, K., 2012. 6th Dubrovnik conference on sustainable development of energy, water and environment systems. J. Clean. Prod. 24, 202-203.

Duic, N., Urbaniec, K., Huisingh, D., 2015. Components and structures of the pillars of sustainability. I. Clean. Prod. 88, 1-12.

Ferreira, V.J., Saez de Guinoa, A., García-Armingol, T., Aranda-Uson, A., LopezSabiron, A.M., Ferreira, G., 2016. Evaluation of the steel slag incorporation as coarse aggregate for road construction: technical requirements and environmental impact assessment. J. Clean. Prod. 130, 175-186.

Fischer, W., Hake, J.-Fr., Kuckshinrichs, W., Schröder, T., Venghaus, S., 2016. German energy policy and the way to sustainability: five controversial issues in the debate on the "Energiewende". Energy 115, 1580-1591.

Gajic, D., Hadera, H., Onofri, L., Harjunkoski, I., Di Gennaro, S., 2017. Implementation of an Integrated Production and Electricity Optimization System in Melt Shop (in this volume).

García-Montoya, M., Sengupta, D., Nápoles-Rivera, F., Ponce-Ortegaa, J.M., ElHalwagi, M.M., 2016. Environmental and economic analysis for the optimal reuse of water in a residential complex. J. Clean. Prod. 130, 82-91.

Gharaie, M., Zhang, N., Jobson, M., Smith, R., Panjeshahi, M.H., 2013. Simultaneous optimization of $\mathrm{CO}_{2}$ emissions reduction strategies for effective carbon control in the process industries. Chem. Eng. Res. Des. 91, 1483-1498.

Giacobbo, A., Meneguzzi, A., Bernardes, A.M., de Pinho, M.N., 2017. Pressure-driven Membrane Processes for the Recovery of Antioxidant Compounds from Winery Effluents (in this volume).

Grobelak, A., Placek, A., Grosser, A., Singh, B.R., Almås, Å.R., Napora, A., Kacprzak, M.,
2017. Effects of Single Sewage Sludge Application on Soil Phytoremediation (in this volume).

Gładysz, P., Ziębik, A., 2015. Life cycle assessment of an integrated oxy-fuel combustion power plant with $\mathrm{CO}_{2}$ capture, transport and storage - Poland case study. Energy 92, 328-340.

Hájek, M., Skopal, F., Vávra, A., Kocík, J., 2017. Transesterification of Rapeseed Oil by Butanol and Separation of Butyl Ester (in this volume).

Hartmann, S., Koval, L., Škrobánková, H., Matýsek, D., Winter, F., Purgar, A., 2015. Possibilities of municipal solid waste incinerator fly ash utilization. Waste Manag. Res. 33, 740-747.

Hassiba, R.J., Al-Mohannadi, D.M., Linke, P., 2017. Carbon Dioxide and Heat Integration of Industrial Parks (in this volume).

Heaslip, E., Costello, G.J., Lohan, J., 2016. Assessing good-practice frameworks for the development of sustainable energy communities in Europe: lessons from Denmark and Ireland. J. Sustain. Dev. Energy Water Environ. Syst. 4, 307-319.

Herrando, M., Cambra, D., Navarro, M., de la Cruz, L., Millán, G., Zabalza, I., 2016. Energy Performance Certification of Faculty Buildings in Spain: the gap between estimated and real energy consumption. Energy Convers. Manag. 125, $141-153$.

Horvat, I., Dović, D., 2016. Dynamic modeling approach for determining buildings technical system energy performance. Energy Convers. Manag. 125, 154-165.

Houri, A., Machaka-Houri, N., 2016. Agave lechuguilla as a potential biomass source in arid areas. I. Sustain. Dev. Energy Water Environ. Syst. 4, 89-93.

Hvala, N., Vrečko, D., Levstek, M., Bordon, C., 2017. The use of dynamic mathematical models for improving the designs of upgraded wastewater treatment plants. J. Sustain. Dev. Energy Water Environ. Syst. 5, 15-31.

ICRP, 2007. The 2007 Recommendations of the International Commission on Radiological Protection.

Iljazi, I., Gebremedhin, A., Abazi, A., 2017. Small-scale University Campus Power Supply Network as a Real Sustainable Energy Laboratory (in this volume).

Kazagić, A., Merzić, A., Redžić, E., Musić, M., 2014. Power utility generation portfolio optimization as function of specific RES and decarbonisation targets - EPBiH case study. Appl. Energy 135, 694-703.

Kilkis, S., 2016a. Sustainable development of energy, water and environment systems index for Southeast European cities. J. Clean. Prod. 130, 222-234.

Kilkis, S., 2016b. Sustainability-oriented innovation system analyses of Brazil, Russia, India, China, South Africa, Turkey and Singapore. J. Clean. Prod. 130, 235-247.

Kilkis, S., Kilkis, S., 2016. Benchmarking airports based on a sustainability ranking index. J. Clean. Prod. 130, 248-259.

Kilkis, S., Wang, C., Björk, F., Martinac, I., 2017. Cleaner Energy Scenarios for Building Clusters in Campus Areas Based on the Rational Exergy Management Model (in this volume).

Knez, M., Obrecht, M., 2016. Policies for promotion of electric vehicles and factors influencing consumers' purchasing decisions of low emission vehicles. J. Sustain. Dev. Energy Water Environ. Syst. http://dx.doi.org/10.13044 j.sdewes.d5.0139.

Kočí, V., Maděra, J., Jerman, M., Žumár, J., Koňáková, D., Cáchová, M., Vejmelková, E., Reiterman, P., Cerný, R., 2016. Application of waste ceramic dust as a ready-touse replacement of cement in lime-cement plasters: an environmental-friendly and energy-efficient solution. Clean. Technol. Environ. Policy 18, 1725-1733.

Kocík, J., Samikannu, A., Bourajoini, H., Ngoc Pham, T., Mikkola, J.-P., Hájek, M. Capek, L., 2017. Screening of Active Solid Catalysts for Esterification of Tall Oi Fatty Acids With Methanol (in this volume).

Kollmann, R., Neugebauer, G., Kretschmer, F. Truger, B., Kindermann, H. Stoeglehner, G., Ertl, T., Narodoslawsky, M., 2017. Renewable Energy from Wastewater - Practical Aspects of Integrating a Wastewater Treatment Plant into Local Energy Supply Concepts (in this volume).

Komušanac, I., Ćosić, B., Duić, N., 2016. Impact of high penetration of wind and solar PV generation on the country power system load: the case study of Croatia. Appl. Energy 184, 1470-1482.

Kovacic, I., Waltenbereger, L., Gourlis, G., 2016. Tool for life cycle analysis of facadesystems for industrial buildings. J. Clean. Prod. 130, 260-272.

Koziol, J., Mendecka, B., 2015. Evaluation of economic, energy-environmental and sociological effects of substituting non-renewable energy with renewable energy sources. J. Sustain. Dev. Energy Water Environ. Syst. 3, 333-343.

Kozlovskiy, R., Shvets, V., Kuznetsov, A., 2017. Technological Aspects of the Production of Biodegradable Polymers and Other Chemicals from Renewable Sources Using Lactic Acid (in this volume).

Kılkış, S., 2015. Composite index for benchmarking local energy systems of Mediterranean port cities. Energy 92, 622-638.

Lambert, T., Gilman, P., Lilienthal, P., 2006. Micropower system modeling with HOMER. Integration Altern. Sources Energy 1 (15), 379-418.

Laskar, M.A., Ali, S.K., Siddiqui, S., 2016. A potential bio-sorbent for heavy metals in the remediation of waste water. J. Sustain. Dev. Energy Water Environ. Syst. 4 , 320-332.

Laso, J., Margallo, M., Fullana, P., Bala, A., Gazulla, C., Irabien, A., Aldaco, R., 2017. Introducing Life Cycle Thinking to Define Best Available Techniques for Products: Application to the Anchovy Canning Industry (in this volume).

Liaqat, U.W., Choi, M., 2017. Accuracy Comparison of Remotely Sensed Evapotranspiration Products and Their Associated Water Stress Footprints under Different Land Cover Types in Korean Peninsula (in this volume).

Maier, S., Szerencsits, M., Narodoslawsky, M., Iqbal, M.I.I., Shahzad, K., 2017. Current Potential of More Sustainable Biomass Production Using Eco Efficient Farming Practices in Austria (in this volume). 
Martinez-Guido, S.I., Sengupta, D., Napoles-Rivera, F., Gonzalez-Campos, J.B., del Rio, R.E., Ponce-Ortega, J.M., El-Halwagi, M.M., 2016. Life cycle assessment for ambrox $^{(8)}$ production from different chemical routes. J. Clean. Prod. 130 202-212.

McNamara, G., Fitzsimons, L., Horrigan, M., Phelan, T., Delaure, Y., Corcoran, B., Doherty, E., Clifford, E., 2016. Life cycle assessment of waste water treatment plants in Ireland. J. Sustain. Dev. Energy Water Environ. Syst. 4, 216-233.

Mikulandrić, R., Vermeulen, B., Nicolai, B., Saeys, W., 2016a. Modelling of thermal processes during extrusion based densification of agricultural biomass residues, Appl. Energy 184, 1316-1331.

Mikulandrić, R., Böhning, D., Böhme, R., Helsen, L., Beckmann, M., Lončar, D., 2016b. Dynamic modelling of biomass gasification in a co-current fixed bed gasifier Energy Convers. Manag. 125, 264-276.

Mikulčić, H., von Berg, E., Vujanović, M., Duić, N., 2014. Numerical study of co-firing pulverized coal and biomass inside a cement calciner. Waste Manag. Res. 32 $661-669$.

Mikulčić, H., Vujanović, M., Duić, N., 2015. Improving the sustainability of cement production by using numerical simulation of limestone thermal degradation and pulverized coal combustion in a cement calciner. J. Clean. Prod. 88, 262-271.

Mikulčić, H., von Berg, E., Vujanović, M., Wang, X., Tan, H., Duić, N., 2016a. Numerical evaluation of different pulverized coal and solid recovered fuel co-firing modes inside a large-scale cement calciner. Appl. Energy 184, 1292-1305.

Mikulčić, H., Klemeš, J.J., Vujanović, M., Urbaniec, K., Duić, N., 2016b. Reducing greenhouse gasses emissions by fostering the deployment of alternative raw materials and energy sources in the cleaner cement manufacturing process. J. Clean. Prod. 136, 119-132.

Mikulčić, H., Cabezas, H., Vujanović, M., Duić, N., 2016c. Environmental assessment of different cement manufacturing processes based on emergy and ecological footprint analysis. J. Clean. Prod. 130, 213-221.

Mohammed, M.A., Budaiwi, I.M., 2013. Strategies for reducing energy consumption in a student cafeteria in a hot-humid climate: a case study. J. Sustain. Dev Energy Water Environ. Syst. 1, 14-26.

Muei Chng, L., Chan, D.J.C., Teong Lee, K., 2016. Sustainable production of bioethanol using lipid-extracted biomass from Scenedesmus dimorphus. J. Clean. Prod. 130, $68-73$.

Narodoslawsky, M., 2015. Sustainable Process Index, Assessing and Measuring Environmental Impact and Sustainability, vol. 3. Butterworth-Heinemann, Oxford, pp. 73-86. http://dx.doi.org/10.1016/B978-0-12-799968-5.00003-8,

Nogueira de Oliveira, L.P., Rodriguez Rochedo, P.R., Portugal-Pereira, J., Hoffmann, B.S., Arag ao, R., Milani, R., Lucena, A.F.P., Szklo, A., Schaeffer, R, 2016. Critical technologies for sustainable energy development in Brazil: technological foresight based on scenario modelling. J. Clean. Prod. 130, 12-24.

Obrecht, M., Knez, M., 2017. Carbon and Resource Savings of Different Cargo Container Designs (in this volume).

Oliveira, L.S.B.L., Oliveira, D.S.B.L., Bezerra, B.S., Pereira, B.S., Battistelle, R.G., 2017 Environmental Analysis of Organic Waste Treatment Focusing on Composting Scenarios (in this volume).

Olmez, G.M., Dilek, F.B., Karanfil, T., Yetis, U., 2016. The environmental impacts of iron and steel industry: a life cycle assessment study. J. Clean. Prod. 130 $195-201$.

Ozturk, E., Koseoglu, H., Karaboyacı, M., Yigit, N.O., Yetis, U., Kitis, M., 2016. Minimization of water and chemical use in a cotton/polyester fabric dyeing textile mill. J. Clean. Prod. 130, 92-102.

Palander, T., 2017. The Environmental Emission Efficiency of Larger and Heavie Vehicles - a Case Study of Road Transportation in Finnish Forest Industry (in this volume).

Petranović, Z Vujanović, M., Duić, N. 2015, Towards a more sustainable transport sector by numerically simulating fuel spray and pollutant formation in diesel engines. J. Clean. Prod. 88, 272-279.

Petranović, Z., Edelbauer, W., Vujanović, M., Duić, N., 2017. Modelling of spray and combustion processes by using the Eulerian multiphase approach and detailed chemical kinetics. Fuel 191, 25-35,

Polomčić, D., Bajić, D., Zarić, J., 2015. Determining the groundwater balance and radius of influence using hydrodynamic modeling: case study of the groundwater source Sumice in Serbia. J. Sustain. Dev. Energy Water Environ. Syst. 3 , 217-229.

Puay, N.-Q., Qiu, G., Ting, Y.-P., 2015. Effect of ZnO nanoparticles on biological wastewater treatment in a sequencing batch reactor. I. Clean. Prod. 88, 139-145. Qiu, G., Wirianto, K., Sun, Y., Ting, Y.-P., 2016. Effect of silver nanoparticles on system performance and microbial community dynamics in a sequencing batch reactor. J. Clean. Prod. 130, 137-142.

Romano, G., Salvati, N., Guerrini, A., 2016. An Empirical Analysis of the determinants of water demand in Italy. J. Clean. Prod. 130, 74-81.

Seo, Y.B., Ahn, J.H., Lee, H.L., 2017. Upgrading Waste Paper by In-situ Calcium Carbonate Formation (in this volume).

Sharan, G., Roy, A.K., Royon, L., Mongruel, A., Beysens, D., 2017. Dew Plant for Bottling Water (in this volume).

Silva, C., Ferreira, A., Dias, A., Costa, M., 2016. A comparison between microalgae virtual biorefinery arrangements for bio-oil production based on lab-scale Results. J. Clean. Prod. 130, 58-67.

Škugor, B., Deur, J., 2016. A bi-level optimisation framework for electric vehicle fleet charging management. Appl. Energy 184, 1332-1342.

Sonetti, G., Chelleri, L., Kikuta, K., 2017. Energy Profiles Collection and Analysis in Two Large Scale University Campuses (in this volume).

Spahiu, A., Dhamo, L., Marango, P., 2017. Economic Analysis of Energy Efficiency Measures in Water Sector (in this volume).

Sriwannawit, P., Anisa, P.A., Rony, A.M., 2016. Policy impact on economic viability of biomass gasification systems in Indonesia. J. Sustain. Dev. Energy Water Environ. Syst. 4, 56-68.

Stefanović, G., Milutinović, B., Vučićević, B., Denčić-Mihajlov, K., Turanjanin, V., 2016. A comparison of the analytic hierarchy process and the analysis and synthesis of parameters under information deficiency method for assessing the sustainability of waste management scenarios. J. Clean. Prod. 130, 155-165.

Suárez, F., Urtubia, R., 2016. Tackling the water-energy nexus: an assessment of membrane distillation driven by salt-gradient solar ponds. Clean. Technol. Environ. Policy 18, 1697-1712.

Swierczynski, M., Stroe, D.I., Stanciu, T., Knudsen Kær, S., 2017. Electrothermal Impedance Spectroscopy as a Cost Efficient Method for Determining Thermal Parameters of Lithium Ion Batteries: Prospects, Measurement Methods and the State of Knowledge (in this volume).

Sýkorová, B., Kucbel, M., Raclavská, H., Raclavský, K., Matýsek, D., 2017. Heavy metals in air nanoparticles in affected industry area. J. Sustain. Dev. Energy Water Environ. Syst. 5, 58-68.

Tabata, T., Zhang, O., Yamanaka, Y., Tsai, P., 2016. Estimating potential disaster waste generation for pre-disaster waste management. Clean. Technol. Environ. Policy $18,1735-1744$.

Tamosiunas, A., Valatkevičius, P., Grigaitiene, V., Valinčius, V., Sriugas, N., 2016. A cleaner production of synthesis gas from glycerol using thermal water steam plasma. J. Clean. Prod. 130, 187-194.

Teixeira, A.C.R., Sodré, J.R, 2016. Simulation of the impacts on carbon dioxide emissions from replacement of a conventional Brazilian taxi fleet by electric vehicles. Energy 115, 1617-1622.

Troy, S., Schreiber, A., Zapp, P., 2016. Life cycle assessment of membrane-based carbon capture and storage Clean. Technol. Environ. Policy 18, 1641-1654.

Urbaniec, K., 2010. UNESCO sponsored 5th Dubrovnik conference on sustainable development of energy, water and environment systems. J. Clean. Prod. 18 (Suppl. 1), S120-S122.

Urbaniec, K., Mikulčić, H., Duić, N., 2016. SDEWES 2014-sustainable development of energy, water and environment systems. J. Clean. Prod. 130,1-11.

Vujanović, M., Petranović, Z., Edelbauer, W., Duić, N., 2016. Modelling spray and combustion processes in diesel engine by using the coupled Eulerian-Eulerian and Eulerian-Lagrangian method. Energy Convers. Manag. 125, 15-25.

Walmsley, M.R.W., Walmsley, T.G., Atkins, M.J., Kamp, P.JJ.., Neale, J.R., 2014. Minimising carbon emissions and energy expended for electricity generation in New Zealand through to 2050. Appl. Energy 135, 656-665.

Wang, T., Zhang, X., Xu, J., Zheng, S., Hou, X., 2015. Large-eddy simulation of flameturbulence interaction in a spark ignition engine fueled with methane hydrogen/carbon dioxide. Energy Convers. Manag. 104, 147-159,

Wang, Y., Tan, H., Wang, X., Du, W., Mikulčić, H., Duić, N., 2017. Study on Extracting Available Salt from Straw/woody Biomass Ashes and Predicting its Slagging/ fouling Tendency (in this volume).

WCED, World Commission on Environment and Development, 1987. The Report of the U.N. Brundtland Commission, Our Common Future. Oxford University Press, Oxford, UK.

Wzorek, M., Tańczuk, M., 2015. Production of biosolid fuels from municipal sewage sludge: technical and economic optimization. Waste Manag. Res. 33, 704-714.

Zakeri, B., Virasioki, V., Syri, S., Connolly, D., Mathiesen, B.V., Welsch, M., 2016. Impact of Germany's energy transition on the Nordic power market - a marketbased multi-region energy system model. Energy 115, 1640-1662. 